Diabetologia $8,292-295(1972)$

(C) by Springer-Verlag 1972

\title{
Insulin Radioimmunoassay by the Charcoal-Dextran Technique*
}

\author{
J.C. Cresto,** I.I. Dujovne, P.I. Castellani, E.A. Mitta, S. F. de Majo, and V. G. Foglia \\ Department of Endocrinlogy, "Dr. Pedro de Elizalde" Pediatric Hospital; Labeled Molecules Division, C.N.E.A.; \\ Instituto de Fisiología, U.N.B.A., Buenos Aires, Argentina
}

Received: January 31, 1972, accepted: February 28, 1972

Summary. The influence exerted by the inactive support (charcoal-dextran) and the proteins in the medium, on the separation of free from antibody-bound ${ }^{125} \mathrm{I}$-insulin by the charcoal-dextran insulin radioimmunoassay method was studied. The behavior of both fractions in the presence of different concentrations of albumin, dextran, normal guinea pig serum, and normal human serum was observed, and the conditions were established under which maximum charcoal adsorption of free insulin and minimum adsorption of bound insulin occur. The results obtained were compared with those yielded by the double antibody technique. - Under these working conditions it is possible to determine insulin in an unknown serum at $1 / 20$ or $1 / 10$ dilutions with a sensibility of $0.5 \mu \mathrm{U}$.

Dosage radio-immunologique de l'insuline au charbondextran

Résumé. Nous avons étudié l'influence exercée par le support inactif (charbon-dextran) et par les protéines dans le milieu sur la séparation de l'insuline libre de l'insuline ${ }^{125} \mathrm{I}$ liée aux anticorps par la méthode de dosage radioimmunologique de l'insuline au charbon-dextran. Nous avons observé le comportement des deux fractions en présence de différentes concentrations d'albumine, de dextran, de sérum normal de cobaye et de sérum humain normal, puis nous avons établi les conditions dans lesquelles se produisent d'une part, le maximum d'absorption d'insuline libre par le charbon, d'autre part, le minimum d'absorption d'insuline liée. Les résultats obtenus ont été comparés avec ceux qui ont été trouvés par la méthode des anticorps doubles. Dans ces conditions de travail, il est possible de déterminer l'insuline dans un sérum inconnu avec des dilutions de 1/20 et 1/10 et avec une sensibilité de $0.5 \mu \mathrm{U}$.

Die radioaktive Insulinbestimmung mit Hilfe der KohleDextran-Methode

Zusammenfassung. Es wurde der Einfluß des inaktiven Trägers (Kohle-Dextran) und des Proteinmilieus auf die Trennung von freiern und an Antikörper gebundenem ${ }^{125}$ I-Insulin auf die radioaktive Insulinbestimmung mit der Kohle-Dextran-Methode untersucht. Das Verhalten beider Fraktionen in Anwesenheit von verschiedenen Konzentrationen von Albumin, Dextran, normalem Meerschweinchenserum und normalem Humanserum wurde studiert und die Bedingungen für eine maximale Adsorption von freiem Insulin an Kohle bei minimaler Adsorption von gebundenem Insulin aufgestellt. Die erhaltenen Ergebnisse wurden mit denen der doppelten Antikörpermethode verglichen. - Unter diesen Arbeitsbedingungen ist es möglich, Insulin in einem unbekannten Serum einer Verdünnung von $1 / 20$ oder $1 / 10$ mit einer Empfindlichkeit von 0,5 $\mu \mathrm{U}$ zu bestimmen.

Key words: Insulin radioimmunoassay, general variables, charcoal-dextran, double antibody.
One of the techniques for insulin radioimmunoassay, first described by Herbert et al. [1], separates antibody-bound antigen from free antigen by means of a dextran-coated charcoal suspension. These authors found that although charcoal adsorbs $99 \%$ of the 131-insulin, it also adsorbs a high percentage of the antibody. The addition of dextran (charcoal-dextran) minimized antibody adsorption without altering insulin uptake, which is still adsorbed in a range of 90 to $95 \%$.

However, Keane et al. [2] believe that there is a $15 \%$ adsorption of gamma globulin which always takes place with this method, and which is impossible to avoid. Therefore, values obtained for plasma insulin by means of the charcoal-dextran technique are subject to an error due to the fact that separation of antibodybound antigen from free antigen is made through a procedure which implies a certain number of inter-

* Supported by grants from Farbwerke Hoechst AG and the International Atomic Energy Agency (Contract 814/RB).

** Fellow of the Argentine National Research Council. actions between the inactive support and the proteins in the medium.

In the present work, we carried out a study of the variables involved in the technique, in order to achieve maximum adsorption of free insulin and minimum adsorption of bound hormone, both of which imply optimum effectiveness of the technic under study.

\section{Methods}

Reagents were prepared according to the original description by Herbert et al. [1]. Since it is known that in this method charcoal adsorption varies with the ionic strenght of the buffer, $\mathrm{pH}$, temperature, etc., these parameters were kept at constant values (see Appendix).

Interactions of the inactive support (charcoaldextran) with insulin and with the insulin-antiserum complex were studied while parameters were individually modified.

Radioactive porcine insulin and guinea pig anti- 
porcine insulin serum (AIS) were incubated for $96 \mathrm{~h}$ at $4^{\circ} \mathrm{C}$. The value found for each parameter resulted from three experimental and three blank tubes ${ }^{1}$. Standard error was calculated in order to determine the precision of the method employed. Since all other ingredients remained constant, whatever changes appeared were necessarily due to the parameter altered in each case.

In the present study we were not interested in the mode of interaction of each variable considered, but rather in its final result: the separation of free from bound antigen fractions.

\section{Study of Interactions}

Independent studies on the influence exerted by albumin, dextran, and normal guinea pig serum (NGPS) concentrations on the separation of free from bound insulin were performed.

While variations in the albumin concentration $(150,350$ or $500 \mathrm{mg} \%$ ) (Fig. 1) did not alter antigen adsorption by charcoal, the percentage of radioactivity of the insulin plus antibody fraction increased. With growing dextran concentrations, (500, 750 or 1000 $\mathrm{mg} \%$ ) the adsorption of free insulin became higher, and the percentage of radioactivity of the insulin plus antibody fraction increased slightly. The addition of NGPS to the buffer up to a final concentration of 1/100 had little effect on the antigen adsorption, but raised further the radioactivity of the insulin plus anti-insulin serum fraction. Fig. 1 also shows that at a $1 / 10$ dilution of NGPS, insulin uptake by charcoal is reduced, without any concomitant increase of the insulin-AIS complex.

On the basis of these observations, we undertook a study of these variables while the remaining parameters were varied in different combinations. As a result of the findings mentioned above, we decided to keep the albumin concentration at a constant value of $500 \mathrm{mg} \%$.

Dextran variable - The behavior of free and anti-

1 The following formula summarizes the analysis performed:

$\%$ of insulin plus

antibody radioactivity $=\frac{\bar{x} E-\bar{x} B}{T-\bar{x} B} \cdot 100$

$\bar{x} E=$ c.p.m., experimental

$\bar{x} B=$ c.p.m., blank

$T=$ total counts

As we were working with a quotient, standard error was calculated by the following formula:

$\widehat{\operatorname{VAR}}\left(\frac{a}{b}\right)=\frac{1}{b^{2}}\left(\widehat{\operatorname{VAR}}(a)+\frac{a^{2}}{b^{2}} \widehat{\operatorname{ARR}}(b)\right)$

S.E. $\left(\frac{a}{b}\right)=\sqrt{\operatorname{VAR}_{\frac{a}{b}}} \quad \begin{aligned} & \text { this result being then multiplied by } \\ & 100 \text { for percentile expression. }\end{aligned}$

Formula (2) is used to calculate the approximate variance of a quotient of independent random variables. This approximation is highly satisfactory when the coefficient of variation of the denominator is small (as in the present case). body-bound insulin as the dextran concentration varied in different situations was studied (Fig. 2).

Variations in dextran concentration did not alter the interaction between insulin and charcoal, but they

$\%$ of radioactivity

in the supernatant
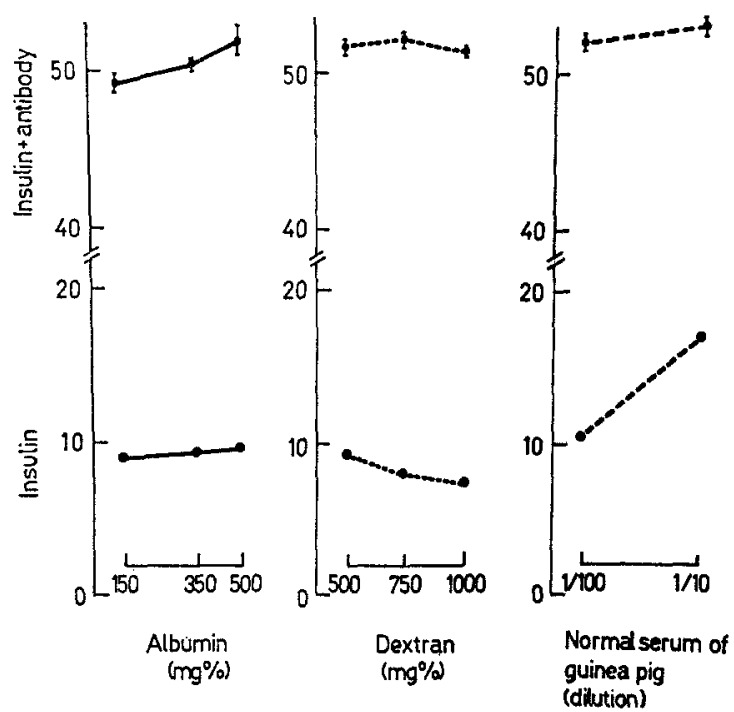

Fig. 1. General study of variables. Individual behavior of albumin, dextran and normal guinea-pig serum.

Albumin; .......... Dextran; ........ Normal Guinea. Pig Serum; $\bar{\bullet}: \bar{x} \pm$ S.E.

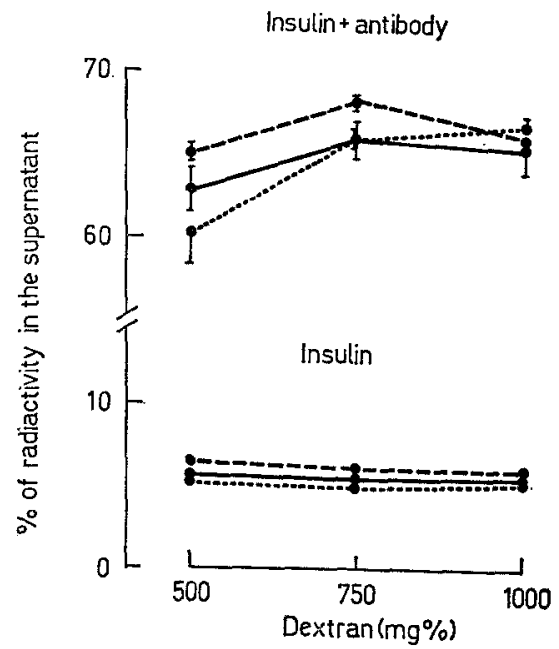

Fig. 2. Dextran variable. Behavior of this variable with different combinations of the remaining variables. Albumin (500 $\mathrm{mg} \%) ; . . . .$. Albumin $(500 \mathrm{mg} \%$ ) and Normal Guinea-Pig Serum $(1 \%) ; \ldots . .$. Albumin $(500$ $\mathrm{mg} \%$ ) and Normal Guinea-Pig Serum $(1 \%$ oo $; \bar{\varphi} \pm \mathbf{x}$ S.E.

raised to a varying degree the percentage of insulin plus antibody radioactivity. The highest point was attained while working with a $1 / 100$ solution of NGPS in buffer containing $500 \mathrm{mg} \%$ human albumin, the charcoal being associated with $750 \mathrm{mg} \%$ dextran. 


\section{Validity of the Method}

The standard curve and the sera were determined according to the scheme shown on Table 1 . After $96 \mathrm{~h}$ incubation at $4^{\circ} \mathrm{C}, 0.5 \mathrm{ml}$ of charcoal-dextran (main-

Table 1. Preparation of the standard curve

\begin{tabular}{lll}
\hline Reagents & $\begin{array}{l}\text { Standard curve } \\
\mathrm{ml}\end{array}$ & $\begin{array}{l}\text { Blank } \\
\mathrm{ml}\end{array}$ \\
\hline Albumin buffer & 0.7 & 0.9 \\
Crystalline insulin $^{\mathrm{a}}$ & 0.1 & 0.0 \\
125I-insulinb $_{\text {Anti-insulin serum }}^{\mathrm{c}}$ & 0.1 & 0.1 \\
\hline
\end{tabular}

\begin{tabular}{|c|c|c|}
\hline \multicolumn{3}{|c|}{ Preparation of the unknown } \\
\hline Reagents & $\begin{array}{l}\text { Experimentald } \\
\text { ml }\end{array}$ & $\begin{array}{l}\text { Blank }^{\mathbf{d}} \\
\mathrm{ml}\end{array}$ \\
\hline Albumin buffer & 0.7 & 0.8 \\
\hline Plasma or serum & 0.1 & 0.1 \\
\hline${ }^{125} \mathrm{I}$-insulin $^{\mathrm{b}}$ & 0.1 & 0.1 \\
\hline Anti-insulin serumc & 0.1 & 0.0 \\
\hline
\end{tabular}

a Insulin concentrations $(\mu \mathrm{U} / 0.1 \mathrm{ml}): 0,2.5,5.0,10.0$, 20.0 , and 40.0 .

b Solution containing $2.0 \mu \mathrm{U} / 0.1 \mathrm{ml}$.

c AIS dilution is $1 / 15500$; therefore its final dilution is $1 / 155000$.

d All determinations are done in duplicate. ditions, the assay of insulin present in one sample of serum shows little dispersion in the course of two months (Table 2). Tables 3 and 4 illustrate reproducibility of results with different volumes of serum, and recovery of porcine insulin added to human serum, respectively; as well as a comparison of values obtained by the charcoal-dextran and double antibody techniques.

Fig. 3 shows the correlation between insulin values assayed by the charcoal-dextran and double antibody methods. A series of sera were assayed by both techniques for that purpose. The correlation found was $r: 0.98(P<0.001)$.

\section{Discussion}

Ideal conditions in the charcoal-dextran technique would be complete adsorption of free insulin and no adsorption at all of antibody. We believe our method is a simple way of approaching this ideal.

Under the working conditions described above, free insulin is almost completely adsorbed, the values in the supernatant being only 5 to $10 \%$. After incubation this figure may rise to $15 \%$ if determinations are made on large volumes of serum $(0.5 \mathrm{ml})$. Serum exerts no

Table 2. Insulin assays on the same serum - reproducibility with the course of time

\begin{tabular}{lllllllll}
\hline Date & $29-10-70$ & $2-12-70$ & $6-12-70$ & $28-12-70$ & $30-12-70$ & $6-1-71$ & $7-1-71$ & $\bar{x} \pm$ S.E. \\
\hline Insulin $\mu \mathrm{U} / \mathrm{ml}$ & 8.0 & 10.0 & 10.7 & 10.5 & 8.8 & 11.7 & 10.7 & $10.05 \pm 0.15$ \\
\hline
\end{tabular}

a Individual determinations were made with 0.05 to $0.5 \mathrm{ml}$ serum.

Table 3. Insulin assays on the same serum - Reproducibility at different dilutions

\begin{tabular}{lllllll}
\hline Serum dilution & $1 / 20$ & $1 / 10$ & $1 / 5$ & $1 / 3.3$ & $1 / 2.5$ & $1 / 2$ \\
\hline $\begin{array}{l}\text { Insulin }(\mu \mathrm{U} / \mathrm{ml}) \\
\bar{x} \pm \mathrm{S} . \mathrm{E} .\end{array}$ & $11.2 \pm 1.58$ & $10.2 \pm 0.95$ & $8.6 \pm 0.68$ & $8.4 \pm 1.36$ & $8.5 \pm 0.5$ & $10 \pm 1.16$ \\
\hline$n$ & 3 & 5 & 4 & 3 & 3 & 3 \\
\hline
\end{tabular}

Table 4. Recovery of porcine insulin added to human serum

\begin{tabular}{|c|c|c|c|c|c|c|c|c|}
\hline & & & & \multicolumn{5}{|c|}{$\mu \mathrm{U}$ poreine insulin added } \\
\hline & & & & 2.5 & $\mathbf{5}$ & 10 & 20 & 40 \\
\hline \multirow[t]{2}{*}{$\mu \mathrm{U}$ insulin recovered } & $\begin{array}{l}\text { charcoal-dextran } \\
\text { technique }\end{array}$ & $\begin{array}{l}\text { Serum } \\
\text { volumes }\end{array}$ & $\begin{array}{l}0.1 \mathrm{ml} \\
0.3 \mathrm{ml}\end{array}$ & $\begin{array}{l}2.5 \\
2.8\end{array}$ & $\begin{array}{l}5.0 \\
5.0\end{array}$ & $\begin{array}{l}8.7 \\
8.7\end{array}$ & $\begin{array}{l}18.4 \\
20.0\end{array}$ & $\begin{array}{l}43.7 \\
-\end{array}$ \\
\hline & $\begin{array}{l}\text { Double-antibody } \\
\text { technique }\end{array}$ & & $\begin{array}{l}0.1 \mathrm{ml} \\
0.2 \mathrm{ml}\end{array}$ & $\begin{array}{l}1.5 \\
2.8\end{array}$ & $\begin{array}{l}3.8 \\
4.6\end{array}$ & $\begin{array}{r}9.0 \\
10.0\end{array}$ & $\begin{array}{l}21.4 \\
21.8\end{array}$ & $\begin{array}{l}40.2 \\
40.0\end{array}$ \\
\hline
\end{tabular}

tained in suspension by constant shaking) were added to each tube, which was then agitated with a vortex mixer and centrifugued at room temperature for $20 \mathrm{~min}$ at $2000 \mathrm{rpm}$. The supernatant of each tube was then counted in a scintillation counter. The graph of the standard curve was plotted according to the original Herbert technique (Co/Cx). Under these con- influence on adsorption of free insulin nor on separation of fractions when volumes below $0.2 \mathrm{ml}$ are used.

Separation of free from bound insulin also depends on the quality of the labeled insulin. Ageing of the insulin (over 20 days after being prepared) alters the results obtained by the charcoal-dextran technique for reasons still unknown. 
Under the conditions described above, the good separation of free from antiserum-bound insulin allows us to carry out assays on unknown sera at $1 / 20$ or $1 / 10$ dilutions with a sensitivity of $0.5 \mu \mathrm{U}$.

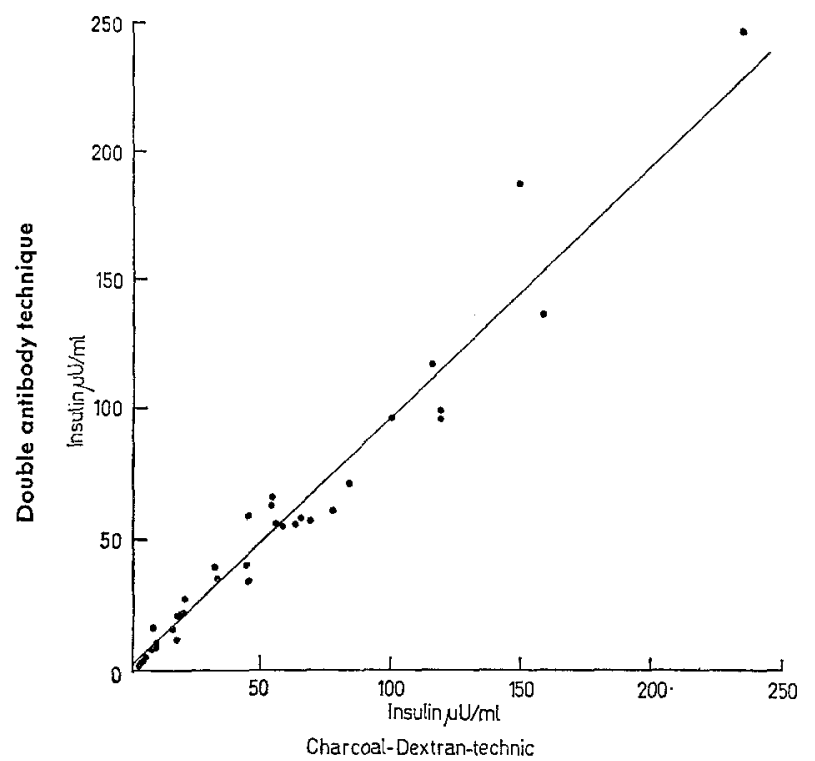

Fig. 3. Linear correlation between the charcoal-dextran technique and the double-antibody technique; $r=0.98$; $y=0.967 ; x+0.615$

\section{Appendix}

Buffer, albumin buffer, charcoal, dextran, and charcoal-dextran were prepared according to Herbert et al. [1] with the following chemicals: Charcoal (activated charcoal, neutral, Merck (R)); Dextran (dextran, MW
80000, Pharmacia (R)); Human Albumin (Behringwerke $(\mathrm{R}))$.

Porcine 125I-Insulin (Hoechst glucagon-free porcine insulin, recrystallized seven times) with specific activity 150 to $200 \mathrm{mC} / \mathrm{mg}$ was provided by the Comisión Nacional de Energía Atómica de la República Argentina (C.N.E.A.), Labeled Molecules Division.

The standard used was porcine insulin (Hoechst) 27 $\mathrm{U} / \mathrm{mg}$

AIS was prepared by innoculation of 15 guinea pigs with porcine insulin in Freund's adjuvant. Each animal received $0.5 \mathrm{mg}$ insulin in $0.5 \mathrm{ml}$ saline plus $0.5 \mathrm{ml}$ Freund's adjuvant in monthly applications for five months. One ml epinephrine (1/100000) was administered prior to each innoculation. One week after the last innoculation the guinea pigs were exsanguinated by cardiac puncture.

The double antibody technique was followed according to Morgan and Lazarow, with slight modifications.

Acknowledgements. The authors wish to thank Mrs. M. García Ben and Mrs. M.C. de Cornet for their statistical and technical assistance, respectively.

\section{References}

1. Herbert, V., Lau, K.S., Gottlieb, C.W., Bleicher, S.J.: Coated charcoal immunoassay of insulin. J. clin. Endocr. 25, 1375-1384 (1965).

2. Keane, P.M., Pearson, J., Walker, W. H.C.: Dextrancoated charcoal immunoassay of insulin. Diabetolo. gia 4, 339-344 (1968)

3. Cresto, J.C., Albani, H., Degrossi, O., Mitta, A.E.A.: Preparación de hormona de crecimiento humano ${ }^{125}$ I y ${ }^{131}$ I de alta actividad especifica en la C.N.E.A. Su aplicaciôn 'in vitro' $\theta$ 'in vivo'. Unpublished.

Juan C. Cresto, M.D.,

Department of Endocrinology,

Pediatric Hospital,

Labeled Molecules Division, C.N.E.A., Institute of Physiology, U.N.B.A., Buenos Aires, Argentina 